\title{
LOGISTICS MODEL FOR INTERNATIONAL BUSINESS OF TUNA LOIN
}

\author{
Mohammad Nofal ${ }^{\bowtie}$, Ira Nuriya Santi, Suryadi Hadi
}

\section{Article's history}

Received November 11 2018

Revised Desember 2, 2018

Accepted January 15, 2019

\section{Key words:}

Business, logistics, tuna loin

\begin{abstract}
This research aims to build a specific logistics model for tuna loin business based on Central Sulawesi resources as a productive supplier for exportation. Four countries are considered as export destinations. They are Singapore, Hong Kong, Taipei, and Vietnam. We have identified a logistics process in which frozen tuna loin flow from factory to the port of Tolitoli, Palu, Bitung, and Makassar, and from these ports commodities are transported only to one transhipment of Surabaya. The four destinations receive tuna loin from this transhipment. Based on our model, the allocation of tuna loin passing through the port of Tolitoli amounted to 37.9 tons, the port of Bitung and Palu 12.5 tons, and the port of Makassar 12.1 tons. The closer the distance from factory to collector port and from transhipment to export destination, the lower the optimal logistics costs.
\end{abstract}

M. Nofal, Ira N. Santi, Suryadi Hadi Economic Faculty of Tadulako University - Indonesia

$\bowtie$ Corresponding author: Nofal_flo@yahoo.com

\section{Introductions}

Tuna loin is one of the fishery commodity traded on the global market, where the commodity flow from producer to consumer going in a logistics network. Therefore, an efficient logistics is crucial to reduce costs or increase profits. According Bawersox (1978), logistics is a strategic management process in the form of goods delivery and storage, including spare parts and finished goods from suppliers, inter company's facilities and to their customers. Ghiani et al (2004), logistics system related to distribution process, warehousing, transportation terminals, the process of those processing, and others.

Central Sulawesi, as one of the producers of tuna loin in Indonesia, has a factory in Doyan Tolitoli. Tuna loin is exported to several countries through some alternative logistics network. The problem faced is that the allocation of tuna loin volume flowing on each alternative network, whether the network of suppliers to the plant or from the factory to the importing countries, has not been optimal, resulting in high logistics costs. In order to solve the problem, a proper logistic model is a must.

Some researchers have been trying to develop logistic and transportation models, but it seems the findings have not fully suited to solve the logistical problems encountered in tuna loin business. In p-Median Model introduced by Hakimi (1965), placing a hub close to the demand point can minimize the movement costs. O'Kelly (1986 and 1987) developed a quadratic models of hub-and-spoke with an interfacility linkage costs causes lower cost but at the same time hub facilities increase. Campbell (1994) formulated p-Hub Median (p-HM), and related it to $\mathrm{p}$-Median (pM). It describes the problem of discrete hub location. Aykin (1995), about one and several hubs provide two solutions: fist is that the movement from the 
origin to the destination through a hub (single), and second to allow the flow from the origin to different hubs (multiple) determined by destination. Zapfel and Warner (2002) integrates operational decisions in a transport system of pure hub-and-spoke to obtain the lowest costs of transportation due to the depot-overlapping cooperation. The model implies efficient logistics as a function of distance, inter-hub interaction, and hub-spoke and logistics operations integration. In fact, the model is suitable for air passengers or cargo air transports with a large volume and relatively stable frequency. However, it is still difficult to be applied to solve tuna-loin logistic problems facing the supply inconsistency with a low quantity.

Kuby and Gray (1993) integrates stop-overs and feeders in a mixed-integer program for a case where a facility location has been determined by analyzing the case of cargo package network managed by Federal Express. In this system, a large-size plane stops in several cities along the flight routes and at each stopover, a feeder route operate small aircrafts to move cargo they carry to larger aircrafts. The model allows less flights but they cause higher loading factors and the total flow distance is reduced. Therefore, saving investment occurs for aircraft, labor and fuel. Besides, feeder routes allow the cities with low parcel quantity connected, so that inefficient small planes can be used for short distances and larger aircrafts can achieve a high load factor for long distances. Stopover and feeder services seem to be close to the fish logistics characteristics. Neverthless, a shortage of fish quantity create extra costs for the waiting times, and the fish flow movement will always be violated.

Wu (2008) examined a logistic relationship between two warehouses, Guangzhou in Southern China and in Hong Kong using three alternative routes : 1) Guangzhou to Hongkong directly by using provider's trucks or two-license rental trucks, 2) Guangzhou to transshipment point located at the border of China territory by using China-license rental trucks. and 3) From transshipment point to Hongkong by using provider's trucks or twolicense rentals.. With one-day logistics data obtained from the logistics company, three tests had been conducted: supply equals demand (test I), supply is greater than demand (test II), and supply is smaller than demand (test III). A mixed integer model specified can indicate the number and the composition of vehicles for each route. Although the model can solve the scenario supply which is smaller than the demand, the transhipment presence for fish logistics may create a significant holding costs that causes inefficient logistics.

Agarwal and Johari (2013) developed an integrated model that can simultaneously minimize distribution costs, optimizing plant location, determining the flow in a network, and determining the composition and the frequency of freights. This multi-echelon model is similar to three-entity logistics model (factories, wholesalers, retailers) analyzed by Ma and Suo (2006), that each echelon has logistics costs: from factories to wholesalers, inventory costs for wholesalers, and product delivery costs from wholesalers to retails. The costs at each echelon can be observed along fish logistics process. Unfortunately, such a model has not been applied for fish logistics. The model used for goods produced by manufactures in a larger volume continuosly without considering holding costs needed to keep fish quality and to wait for fish sufficient quantity to be transported to the destination.

The study has an objective to build a specific logistics model for tuna loin business based on Central Sulawesi resources as a productive supplier for exports. We are trying to solve the problem of the inefficient tuna loin logistics by having definite supplier and factory location, by organizing supply network configuration that assures optimal quantity flows efficiently.

\section{Method}

This research is to build a specific logistics model for tuna loin, a commodity which has an international market. The model should include all levels of the logistics network in which commodity flows until it reaches the destination countries. In accordance with the facts, we consider the four countries as export destinations, they are Singapore, Hong Kong, Taipei, and Vietnam. The research has been conducted with the following steps:

1. Describing the international logistics network for Central Sulawesi's tuna loin. 
2. Integrating international logistics network in the domestic model we found earlier.

3. Building a model of international logistics.

4. Conducting a logistics survey.

5. Optimizing model based on survey data.

Logistics datas consist of relevan informations on capacity and cost, collected by tracing the various levels of logistics network. Therefore, the survey has been conducted both within and outside the region of Central Sulawesi, according to the direction of the logistics network being investigated.

\section{Result}

$\underline{\text { Model }}$

There are several logistics network through which the tuna loin produced in Central Sulawesi reach the importing countries. As shown in Figure 1 in appendix, unfinished tuna loin is delivered by four suppliers to just one factory for further processing, such as trimming, CO treatment, vacuum, freezing and storage. The product is then transported to the port of Tolitoli, Palu, Makassar, and Bitung (collector ports). Because of Surabaya is a sole transhipment for export, the tuna loin received in four ports should be forwarded to this transhipment. Four export destinations each receive tuna loin from Surabaya. Based on these facts, a problem faced is how should the allocated tuna loin on networks from each collector ports to transhipment and from transhipment to each of four export destination countries, so the logistics costs can be minimized. This problem can be solved with a proper logistic model. A fish logistic model at the domestic level, developed by Nofal at al. (2015), can be expanded to address this problem, taking into account the export network as shown in Figure 1. For this purpose, the parameters of the model should be adjusted as follows:

$I$ : the total volume of tuna loin

$S:$ the number of suppliers

$P$ : the number of factory (1 factory)

$E:$ the number of export destinations

$K s$ : tuna loin capacity on supplier $s$

$K p$ : storage capacity of tuna loin in factory $\mathrm{p}$

$D e$ : demand for tuna loin in the destination e

Csp: logistics cost-per-kilogram of tuna loin from suplier to factory $\mathrm{p}$

$F p$ : processing-cost-per-kilogram of tuna loin in factory $\mathrm{p}$

Cpe: delivery cost-per-kilogram of tuna loin transported from factory $\mathrm{p}$ to destination e.

The following are three decision variables :

$x s p$ : the volume of tuna loin transported from suplier $s$ to factory $p$

$x p e$ : the volume of tuna loin transported from factory $p$ to destination $e$

$y p$ : is binary, valued 1 if the tuna loin is flowed through the factory $p$ and 0 otherwise.

$\operatorname{Min} \sum_{p=1}^{P} \quad \sum_{s=1}^{S} C_{s p} X_{s p}+\sum_{s=1}^{S} y_{p} F_{p} I_{p}+\sum_{e=1}^{E} \quad \sum_{p=1}^{P} C_{p e} X_{p e}$ Mixed integer programming is specified to minimize the total logistics costs is shown below:

subject to :

1). The tuna loin volume transported to factory from suppliers does not exceed the tuna loin on the suppliers :

$$
K_{s} \geq \sum_{s=1}^{S} X_{s p} \quad \forall s, p
$$


2). Factory capacity does not exceed the tuna loin volume transported to factory :

$$
K_{p} \leq \sum_{s=1}^{S} X_{s p} \quad \forall s, p
$$

3). The tuna loin volume transported to the expor destinations from factory does not exceed the factory capacity :

$$
K_{p} \geq \sum_{e=1}^{E} X_{p e} \quad \forall p,
$$

4). The tuna loin volume transported from factory to export destination does not exceed the tuna loin transported to the factory :

$$
\sum_{s=1}^{S} X_{s p}=\sum_{e=1}^{E} X_{p e} \quad \forall s, p, e
$$

5). All customer demands at the destinations can be satisfied :

$$
D e=\sum_{e=1}^{E} x_{P e} \quad \forall e
$$

6). All continuous variables $x_{s p}$ and $x_{p e}$ are positive :

$$
\begin{array}{ll}
x_{s p} \geq 0 & \forall_{s, p} \\
x_{p e} \geq 0 & \forall_{p, e}
\end{array}
$$

7). Decision variable $y_{p}$, is binary :

$$
y_{p} \in\{0,1\} \quad \forall_{p}
$$

Because there is only one factory, processing costs are not considered, so that $F_{\mathrm{p}}$ equal to zero.

\section{Discuss}

\section{Logistics Capacity and Costs}

A commodity to be analized in this research is tuna loin of yellowfin species. For a whole tuna, four piece of filet can be made with a portion to loin is $50 \%$. It is because of the wasted product, consisting of head, skin and bones (15\%); meat eroded (25\%); stomach and gills $(10 \%)$. Tuna loin is produced firstly in several fish landing. During the fishing season of tuna, all eight fish landings are capable to produce for 75.400 kilogram of tuna loin a month, derived from a number of 3,080 yellow fin or 150.8 tons. The production capacity in each fish landing is shown in Table 1 in appendix. The largest quantity of loin production is found at fish landing Lingadan and the least in Kampung Pajala.

Our approach in identifying the logistics costs is to trace all levels of logistics network. Logistics costs along the route of suppliers to factory are borned by supplier, consisting of costs of streoform box, ice, and transport. As shown in Table 2 Panel A in the appendix, a streoform box cost is obtained by dividing the daily cost (the acquisition cost divided by duration of use) with a quantity of tuna loin in one box a day. The unit cost is Rp. 23 and be equal for all supliers. Ice cost is obtained by dividing the purchase price of ice placed in each streoform box with a quantity of tuna loin in the same box. The ice cost calculated is Rp. 
800 per-kilogram. The high cost of ice because suppliers are still using ice packs instead of ice cubes fabricated.

Supplier Baolan and Lingadan use their own cars to deliver tuna loin to the factory, while three other suppliers are still using public transportation vehicles. For the own car transportation, logistics costs take account for the cost of depreciation, oil, tires, fuel and driver salaries. Unit logistics cost is obtained by dividing the total monthly cost with the quantity of tuna loin transported for a month. For the public transportation, the logistics cost is obtained by dividing cost per box with the quantity contained in that box. As shown in Table 2, delivery cost from fish landing Baolan and Lingadan to the factory, with private cars, each only Rp. 125 and Rp. 185 per kilogram. For public transportation, the cost from fish landing Laulalang to factory is Rp 3,333 per kilogram, from fish landing Salumpaga and Buol to factory is Rp. 5,000 per kilogram. The cost of transportation is very significant in the totality of logistics costs. The logistics costs from fish landing Baolan and Lingadan to the factory are respectively Rp 948 and Rp 1,008 per kilogram, from fish landing Salumpaga and Buol to the factory are Rp 5,823 per kilogram, and from fish landing Laulalang to the factory are $\mathrm{Rp} 4,157$ per kilogram.

Mean of transport used in factory to collected port network is thermoking truck with a capacity of 4 tons. With a cost of transportation from factory to the port of Bitung is Rp $6,000,000$ for a trip, unit transportation cost is Rp. 1,500 per-kilogram. Given a distance between factory to port of Bitung is 821 kilometers, the average transportation cost for each kilometer is Rp. 1.83 per-kilogram. Based on this average unit cost, we can determine the tuna loin transport costs from factory to the port of Palu and Makassar, using thermoking truck, by multiplying the distance with the unit cost. Table 2 panel B in appendix show the calculation results. In general, the unit transport cost increase with the distance.

The reason why all areas in eastern Indonesia, especially Sulawesi, is difficult to export tuna loin on their own because of the volume of tuna loin is very small relative to the vessel capacity. This condition forced the provider to collect tuna loin in Surabaya before export. Tuna loin has been shipped from the port of Toli Toli, Palu, Bitung and Makassar to Surabaya using a 20 'reefer container. The current datas on 20' reefer container fare are obtained from the owner of the goods and logistics provider, as shown in Table 2 panel $\mathrm{C}$ in Appendix. As seen, the unit cost of transport with a reefer container is different depending on the collector port location, given the same volumes of tuna loin. The lowest cost occurs in Makassar to Surabaya route and the highest in Tolitoli to Surabaya route.

Tuna loin from the previous port, after arriving in Surabaya, was transferred to a 40 "reefer container and loaded on larger vessels to be brought to each of four export destinations, together with other commodities. Table 2 panel D in appendix shows provider's data on transportation cost of tuna loin shipping from Surabaya to four export destinations. As shown, the unit cost from Surabaya to Vietnam is Rp 1,242 per kilogram, to Taipei is Rp 1,155 per kilogram, to Hongkong is Rp 982 per kilogram, and to Singapore is Rp 895 per kilogram.

\section{Optimized Results}

The model was applied to logistics data of tuna loin as discussed above. The allocation of volume on each network is optimized using software Analytic Solver Platform V 2016. The results are summarized in Table 3 in appendix.

As shown in Table 3, the amount of tuna loin flowing in the logistics process is equal to 75 tons. Export destinations are Singapore, Hong Kong, Taipei and Vietnam. In general, the supply allocation on the Port of Tolitoli, Palu, Makassar and Bitung is no different for all cases: 37.9 tons pass through Tolitoli, 12.5 tons pass through Palu and Bitung, and 12.1 tons pass through Makassar. In other words, tuna loin business with a destination of four countries can be carried out simultaneously.

In the cases where the factory meets the tuna loin demand for all four countries in the same volume, respectively 18.75 tonnes, the minimum logistics costs are $R p \quad 442,763,238$. The minimum logistics costs are associated with supply allocations, where Tolitoli supply to all 
three countries, Palu and Makassar each to one country, and Bitung to two countries. All routes pass through transhipment Surabaya to achieve export destinations. The results changed in the case where Vietnam received three containers while the other three countries are 12.5 tons. Total logistics cost is Rp 447,094,325, is greater than the cost-optimized in the previous case. At this cost, allocation is that Tolitoli supply to all four countries while Palu, Makassar and Bitung each supplying only to one country. If we sent Taipei 3 container while the other three countries are 12.5 tons, the minimum costs decreased to Rp 444, 928.782, but it is still greater than the first case. For this situation, allocation is that Tolitoli supply to all three countries, Palu and Makassar to one country, and Bitung to two countries.

We then change the composition of demand to meet the Hongkong 3 container while the other three countries are only 12.5 tons. In this case, the minimum total costs are Rp $440,597,695$, it is lower than the cost in the first case. The related supply allocation is that Tolitoli, Palu and Bitung supply to two countries while Makassar is only to one country. Finally, when Singapore is supplied three containers and three other countries each only 12.5 tons, the minimum total cost is the Lowest of all cases, the which amounted to Rp 438, 432.151. In this case, Tolitoli, Palu and Bitung supply to two countries while Makassar only to one country.

For every case that has been analyzed, it was suggested that the tuna loin that must be transported through Tolitoli port approximately $51 \%$ of the total supply. it is easy to understand because factory is very close to the port. However, our results concerning the lowest cost on the route Surabaya-Singapore are particularly interesting to compare with the existing logistics theory.The result is compatible to the conclusion of p-Median model introduced by Hakimi (1965), in which placing a hub location close to demand point can minimize the cost of movement. In fact, Singapore have the shortest distance to Surabaya, compared with the three other countries considered in the study. In other words, the high logistics cost on the route of Tolitoli to Surabaya can be compensated by the lower logistics costs on the route of Surabaya to Singapore, resulting in lowest logistics costs. However, the result is in contrast to the conclusion of hub-and-spoke quadratic model found by O'Kelly (1986 and 1987), in which the costs decrease with increasing hub. The difference is caused by the absence of interfacility linkage in tuna loin business.

\section{Conclusion}

This study builds a logistic model for the international business of tuna loin commodity produced in Central Sulawesi, Indonesia. Four export destination countries are considered, including Singapore, Hong Kong, Taipei, and Vietnam. The model is a mixed integer programming with the objective function is to minimize logistics costs.

Optimizing the model using logistics datas, it resulted in the allocation of tuna loin on any network with a minimum level of logistics costs. In all cases analized, The supply allocation of tuna loin pass through the port of Tolitoli is 37.9 tons, 12.5 tons go by the port of Palu and Bitung, and 12.1 tons go by the port of Makassar. It is to say that tuna loin trading from Central Sulawesi to all four countries considered can be carried out simultaneously. The closer the distance from factory to collector port and from transhipment to export destinations, the lower the cost of logistics.

Our result support the conclusion of p-Median models introduced by Hakimi (1965), in which the placement of hub close to the demand point can minimize the cost of movement. However, the results obtained are opposite to the conclusions of hub-and-spoke quadratic model found by O'Kelly (1986 and 1987), in which costs decline with increasing hub. The difference is caused by the absence of interfacility linkage in tuna loin business. In contrast to O'Kelly, in this study, it is advisable to reduce the number of hubs.

\section{References}


Agarwal S. and K. Johari. 2013. Mathematical Modelling In Transportation Sciences. Journal of Mathematics 5, 39-43.

Aykin, T. 1995. Networking policies for hub-and-spoke systems with applications to the air transportation system. Transportation Science 26, 201-221.

Bowersox D. J. 1978. Logistical Management, Macmillan Publishing Co. Inc USA. Campbell, J.F. (1994), Integer programming formulations of discrete hub location problems. European Journal of Operational Research 72, 387-405 North-Holland.

Ghiani G., G. Laporte G. and R. Musmanno. 2004. Introduction to Logistics Systems Planning and Control, JohnWiley \& Sons, Ltd.

Hakimi, S. L. 1965. Optimum Distribution of Switching Centers in a Communication Network and Some Related Graph Theoretic Problems. Operations Research 13, 462475.

Kuby M. J. and R. Gray. 1993. The Hub Network Design Problem With Stopovers and Feeders the Case of Federal Express. Transportation Research Part A-Policy and Practice 27(1), 1-12.

Ma H. and C. Suo. 2006. A Model for Designing Multiple Products Logistics Networks. International Journal of Physical Distribution \& Logistics Management, Vol. 36 Iss 2 pp. $127-135$.

Nofal M., A. A. Adam, and S. Hadi. 2015. Designing Fish Logistics System for Indonesia based on Central Sulawesi Resources, Proceedings of International Conference on Aquaculture \& Fisheries. Journal of Aquaculture Research \& Development, Vol. 6, Issue 6, July 2015.

O'Kelly, M. E. 1986. The Location of Interacting Hub Lacilitics. Transportation Science, Vol. 20, 92-106.

O'Kelly, M. E. 1987. A Quadratic Integer Program for The Location of Interacting Hub Facilities. European Journal of Operational Research Vol. 32 pp. 393-404.

Zapfel G. and M. Wasner. 2002. Planning and Optimization of Hub-and-Spoke Transportation Networks of Cooperative Third Party Logistics Providers. International Journal Production Economic Vol. 78 pp. 207-220.

Wu Y. 2008. A Mixed-Integer Programming Model for Global Logistics Transportation Problems. International Journal of Systems Science Vol. 39, No. 3, March, 217-228. 


\section{Appendix :}

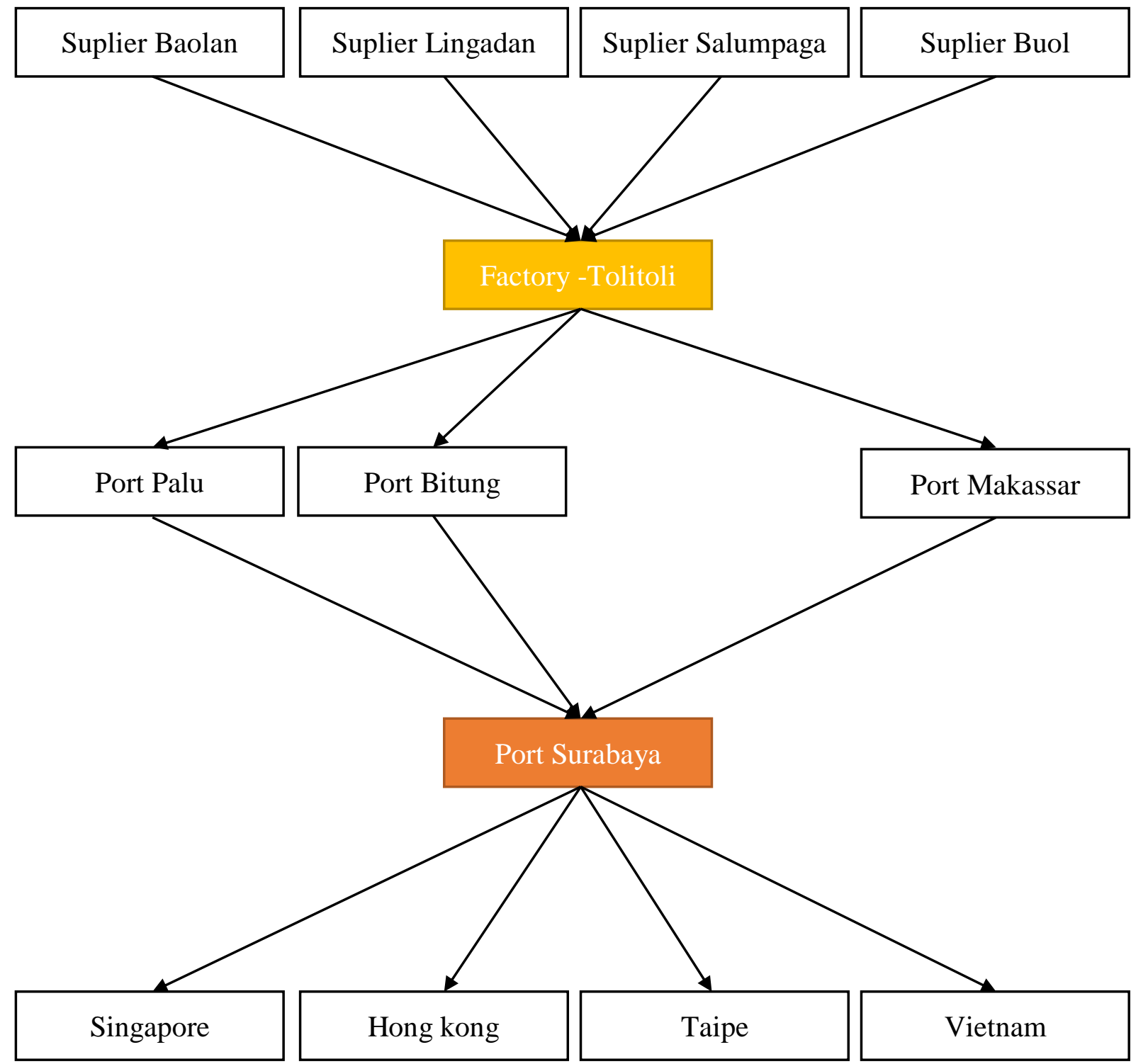

Figure 1. The logistics network of tuna loin 
Tabel 1. Production capacity of tuna loin by fish landings

\begin{tabular}{ccr}
\hline No & Fish landings & Production per-month $(\mathbf{k g})$ \\
\hline 1 & Bantayan & 18,000 \\
2 & Lutungan & 3,600 \\
3 & Ogotua & 3,000 \\
4 & Kampung pajala & 1,300 \\
5 & Salumpaga & 15,000 \\
6 & Laulalang & 3,500 \\
7 & Lingadan & 25,000 \\
8 & Buol & 6,000 \\
\hline & Total & 75,400 \\
\hline
\end{tabular}

Sources : Field survey results, 2016.

Tabel 2. Logistics costs of Tuna-loin

\begin{tabular}{|c|c|c|c|c|c|c|}
\hline \multicolumn{7}{|c|}{ Panel A : Logistics costs of tuna loin from supplier areas to the factory } \\
\hline \multirow{2}{*}{ No } & \multirow{2}{*}{ Destination } & \multicolumn{5}{|c|}{ Supplier locations (Rp/kg) } \\
\hline & & Baolan & Lingadan & Salumpaga & Laulalang & Buol \\
\hline 1 & Factory & 948 & 1,008 & 5,823 & 4,157 & 5,823 \\
\hline \multicolumn{7}{|c|}{ Panel B : Logistics costs from the factory to the collector ports using thermoking truck } \\
\hline \multirow{2}{*}{ No } & \multirow{2}{*}{ Origin } & \multicolumn{5}{|c|}{ Destinations (Rp/kg) } \\
\hline & & Tolitoli & Bitung & Palu & \multicolumn{2}{|c|}{ Makassar } \\
\hline 1 & Factory & 0 & 1,500 & 748 & \multicolumn{2}{|r|}{2,266} \\
\hline \multicolumn{7}{|c|}{ Panel C : Shipping cost per-kilogram to Surabaya using $20 "$ reefer container } \\
\hline \multirow{2}{*}{ No } & \multirow{2}{*}{ Destination } & \multicolumn{5}{|c|}{ Origins (Rp/kg) } \\
\hline & & Tolitoli & Palu & Bitung & \multicolumn{2}{|c|}{ Makassar } \\
\hline 1 & Surabaya & 1,640 & 1,600 & 1,520 & & 1,040 \\
\hline \multicolumn{7}{|c|}{ Panel D : Shipping cost per-kilogram to destination countries using 40" reefer container } \\
\hline \multirow{2}{*}{ No } & \multirow{2}{*}{ Origin } & \multicolumn{5}{|c|}{ Destinations (Rp/kg) } \\
\hline & & Singapore & Hongkong & Taipe & Vietn & \\
\hline 1 & Surabaya & 895 & 982 & 1,155 & & 1,242 \\
\hline
\end{tabular}

Sources : field survey and logistics provider data's, 2016. 
Tabel 3. Summary of optimized results

No Deskription Kg/Rp Tolitoli
A Base - equal volume

Total volume and alocation $(\mathrm{kg})$ :

Singapore
Hongkong
Taipe

75.000

37.900

18.750

18.750

Vietnam

18.750

18.750

18.750

18.750

400

Transported by (kg) :

Palu Bitung Makassar

442.763.238

Minimum logistics costs (Rp) :

B Vietnam - 3 reefer container

Total volume and alocation $(\mathrm{kg})$ :

Singapore
Hongkong
Taipe
Vietnam

Minimum logistics costs (Rp) :

C Taipe - 3 reefer container

Total volume and alocation $(\mathrm{kg})$ :

$$
\begin{gathered}
\text { Singapore } \\
\text { Hongkong } \\
\text { Taipe } \\
\text { Vietnam }
\end{gathered}
$$

$\mathbf{7 5 . 0 0 0}$
12.500
12.500
37.500
12.500

37.900

$12.500 \quad 12.500$

12.100

12.500

12.500

12.900

$12.500 \quad 12.100$

400

12.100

444.928.782

D Hongkong - 3 reefer container

Total volume and alocation $(\mathrm{kg})$ :

Singapore
Hongkong
Taipe
Vietnam

75.000

37.900

12.500

12.500

12.100

12.500

12.500

37.500

25.400

12.500

12.500

440.597.695

Minimum logistics costs (Rp) :

E Singapore - 3 reefer container

Total volume and alocation $(\mathrm{kg})$ :

Singapore
Hongkong
Taipe

Vietnam

Minimum logistics costs (Rp) :

$\begin{array}{rrrrr}\mathbf{7 5 . 0 0 0} & \mathbf{3 7 . 9 0 0} & \mathbf{1 2 . 5 0 0} & \mathbf{1 2 . 5 0 0} & \mathbf{1 2 . 1 0 0} \\ 37.500 & 37.500 & & & \\ 12.500 & 400 & 12.100 & & \\ 12.500 & & 400 & 12.100 & \\ 12.500 & & & 400 & 12.100\end{array}$

12.100

$400 \quad 12.100$

$400 \quad 12.100$ 